\title{
Becoming a Librarian Amidst a Professional Identity Crisis
}

\section{Ashley Edwards ${ }^{1}$}

${ }^{1}$ School of Library and Information Studies, University of Alberta, Email: aedwards@ualberta.ca

To Cite:

Edwards, A. (2020). Becoming a librarian amidst a professional identity crisis. [Special Issue]. Pathfinder: A Canadian Journal for Information Science Students and Early Career Professionals, 1(1), 3-9. https://doi.org/10.29173/pathfinder17

\section{Abstract}

Adopted in the late 1930s, the Library Bill of Rights grounded the profession in the core value of intellectual freedom. This core value was challenged in the 1930s, the 1960s, the 1990s, and again in recent years by calls for social responsibility within our ranks.

The recurrent discomfort with upholding intellectual freedom is particularly evident today in the case of public library third-party meeting room bookings by controversial speakers. Both the Toronto Public Library and the Vancouver Public Library have come under scrutiny by both specific voices within the field as well as the community more broadly. This is not the first time, nor will it be the last time, that publicly funded libraries are faced with controversy surrounding intellectual freedom. Using critical information theory, this presentation examines important questions: How is intellectual freedom defined, redefined, and confined today? What is the relationship between the core value of intellectual freedom and related core values such as social responsibility and diversity? How do we uphold professional ethics (e.g., International Federation of Library Associations and Institutions Code of Ethics for Librarians and Other Information Workers) in instances when our personal, professional, institutional, and/or association commitments do not align? These questions are rooted in my ongoing academic explorations with Dr. Toni Samek as a University of Alberta School of Library and Information Studies 2019_ 20 research assistant on the nature and extent library and information studies curricula (for both professionals and paraprofessionals) prepares graduates to negotiate the perpetually complicated core value of intellectual freedom from a position of confidence and not fear, defensiveness, or divisiveness.

Keywords: Intellectual Freedom, LIS curriculum, Professional identity, Room bookings

Pathfinder: A Canadian Journal for Information Science Students and Early Career Professionals, 1(1), 3-9. 
I

want to begin by acknowledging that I am located on the unceded, current, and traditional territories of the həńqəmińəḿ- and Skwxwú7mesh-speaking peoples, including the Tsleil-Waututh, Qayqayt, Stz'uminus, Musqueam, and Kwikwetlam First Nations. The land is now known as Burnaby, B.C., a suburb of Vancouver. I would also like to acknowledge the privilege of growing up on Stó:Iō territory in the Fraser Valley. Learning the histories of where I am is part of my personal decolonization practice.

Before delving into the complex topic of intellectual freedom and our professional identity, I want to take a moment to position myself within this research. An important aspect of any research is understanding and naming your positionality. This doesn't mean my position on the topic (as you'll see l'm struggling with that still), but how who I am influences my work. In Indigenous research methodologies, this is my relational accountability - to whom I am accountable. In this case I am accountable not only to my family, but also my fellow librarian students and my colleagues at Simon Fraser University. Part of this is recognizing, or trying to recognize, my own biases when l'm doing research. The question is often what to do about them: ignore them or allow them to guide my work? I'm still unsure about that answer.

According to Shawn Wilson (2008), it's an Indigenous paradigm to create a relationship with your topic and the ideas you are working with as a researcher. Wilson (2008) also says it's a Western tradition to "amputate" yourself during your work (i.e., remove emotion from intellect, be professional not emotional). If you don't compartmentalize things, your research will influence all aspects of your life; it changes you.

I'm approaching this work with a decade of library experience, mostly in an academic library, as a library technician. There are LGTBQA2S+ people in my family and friends. My heritage is Metis-settler, though I didn't grow up within that community. I'm the oldest of four children, and my parents divorced when I was twelve. These experiences make up the biases that I bring with me, that guide my work.

My presentation is on intellectual freedom, the controversy surrounding room bookings, and professional identity. This is a huge topic, one that could be studied for years rather than the five months l've been working with Dr. Samek as part of my graduate research assistant position. 
To set the context, the controversy is public libraries permitting third-party room bookings by groups questioning transgender rights-specifically those of transgender women. Each group is bringing Meghan Murphy, founder of the website the Feminist Current. Murphy has been banned from Twitter due to her refusal to use preferred pronouns and deadnaming individuals (Goodyear, 2019). She is concerned about trans women using women's change rooms, playing sports on female teams, being in female prisons, and accessing services such as transition houses for those leaving abusive relationships (Murphy, 2019; Nickle, 2019). She has also repeatedly stated that men cannot be women, but also that she's not anti-trans ("Event featuring Meghan Murphy," 2019; Murphy, 2019; The Canadian Press, 2019).

Specifically, she has spoken out against An Act to Amend the Canadian Human Rights Act and the Criminal Code (Bill C-16), passed by the Canadian House of Commons and Senate in 2017, which added gender expression and gender identity as being protected under the Canadian Human Rights Act against discrimination. In her view it jeopardizes women's rights (“Event featuring Meghan Murphy," 2019; Goodyear, 2019; Murphy, 2019; Nickle, 2019; The Canadian Press, 2019).

In 2019 and 2020, Murphy was invited to speak at several events held in public libraries: Vancouver Public Library, Toronto Public Library, and the Seattle Public Library. A planned event for the New York Public Library was cancelled.

The transgender community and their allies were naturally upset about these events. People have claimed what Murphy is saying is hate speech and should not be allowed in a publicly funded institution (“Event featuring Meghan Murphy," 2019). It's claimed that public libraries have been chosen to add legitimacy to the speaker and topic (Slaughter \& MacLeod, 2019). The libraries state they have allowed room bookings based on intellectual freedom.

The question is, should libraries be denying these radical feminist groups their room booking? Is that in conflict with the value of intellectual freedom? Or, is intellectual freedom in conflict with other values, such as diversity and inclusion? What does this mean for the professional identity of library staff?

The research I've done about this topic has been exploratory. I don't have answers for the above questions. Rather, l'd like to see this conversation happening within 
library settings. One part of that conversation l've been having with my SLIS cohort is how, as students nearing the end of our programs, we don't feel prepared to enter this debate. Not everyone has taken the Intellectual Freedom and Social Responsibility course, and the subject hasn't necessarily come up in other classes. When it (or similar topics) has, our professors have given us space to explore and challenge not only each other but also the course readings and ourselves as we develop our professional opinions and beliefs. It's also understood that these may change during our careers as we gain experience and continue learning. It is the SLIS mission to foster "diverse, reflective and inquiring library and information leaders," which to me means we don't stop our education when the program ends. This is just the beginning.

Throughout the reading l've done for this presentation, it became very obvious that the profession is divided on this issue. One librarian put forward that the divisiveness we are seeing is a divide between those in management (aka those with power) and those on the front lines who may be members of a marginalized community themselves (Neigel, 2019). A trio of academic library deans and university librarians called out the Canadian Federation of Library Associations for using an outdated and simplified definition of what intellectual freedom means, urging for an updated policy that reflects a balance between intellectual freedom and human rights (Bird et al., n.d.). Others question why this is the issue that's gaining people's attention and not other events centred on equally questionable behaviour (Beaudry, 2019). Additionally, highly charged media accounts, sometimes with personal attacks, have become the norm for this situation. For myself, and my cohort, are we prepared for these nuanced conversations? Our education hasn't always taught us the ways in which libraries have not been neutral. Add in the fact that librarian work (professional and paraprofessional) is a feminized profession and the stigma that exists for females in management positions (Gluckman, 2018; Smith et al., 2018). There is a lot to consider.

As I've been engaging with the media reports about the controversy, literature about libraries and intellectual freedom, and gender politics, l've also been learning about two theories: intersectionality and critical librarianship. In an article published by In the Library with a Lead Pipe, Ettarh (2014) writes about intersectional theory and librarianship, stating that "various categories of marginalization and identity interact on 
multiple (and often simultaneous) levels." In other words, the pieces of a person's identity cannot be looked at separately because they intersect and influence each other. As a result, people should not be looked at through one lens-you won't get the full picture. Should we be looking at organizations and their policies using intersectionality? To do so we may need to employ critical librarianship, explained by the Association of College and Research Libraries Instruction Section Research \& Scholarship Committee (2017) as taking an "ethical and political approach to library work, using critical theory to expose and question the historical, political, and social bases of our assumptions and practices."

As we finish our formal education and begin our professional lives, it's important to remain open-minded and willing to engage in these tough conversations. One prominent theme within the reading l've done is that learning or change cannot occur without dialogue. The library profession is having an identity crisis, not just because of this controversy, but also in response to The Truth and Reconciliation Commission of Canada's Calls to Action (2015) and the need to decolonize the institution and education. The profession is being called upon to recognize and address its foundations in colonization, oppression, and white supremacy; this controversy is just one example. It's also an example of how easily divided colleagues, leaders, and our communities can become.

Through our discussions on this, Dr. Samek and I have talked about how this is a key moment in the history, and future, of libraries. As a student, this controversy and subsequent identity crisis made apparent how many of my courses could have talked about the nuances of librarianship and addressed the darker history of libraries. While I have enjoyed this program, and am looking forward to beginning my new career, if I was starting it now I would hope for more uncomfortable conversations, outside of the course Intellectual Freedom and Social Responsibility. Going forward, these topics will be ones I pursue in my professional development. This program, and graduate research assistant position, has been an introduction to them, but my education doesn't end here. 


\section{References}

Association of College and Research Libraries Instruction Section Research \& Scholarship Committee. (2017). Five things you should know about critical librarianship. https://acrl.ala.org/IS/wp-content/uploads/20170602_research_5Things.pdf

Beaudry, R. (2019, December 16). Intellectual freedom debate: Why Megan Murphy and why now? Centre for Free Expression.

https://cfe.ryerson.ca/blog/2019/12/intellectual-freedom-debate-why-meganmurphy-and-why-now

Bird, G, Lew, S., \& Mundle, T. (n.d.). Open letter to the CFLA Board.

https://www.change.org/p/canadian-federation-of-library-associations-open-letterto-cfla-board

Ettarh, F. (2014, July 2). Making a new table: Intersectional librarianship. In the Library with a Lead Pipe. http://www.inthelibrarywiththeleadpipe.org/2014/making-a-newtable-intersectional-librarianship-3/

Event featuring Meghan Murphy ignites debate about libraries' role as forum for free speech. (2019, October 30). Edmonton Journal. https://edmontonjournal.com/

Gluckman, P. R. (2018, August 28). When women are called 'aggressive' at work. Forbes. https://www.forbes.com/sites/nextavenue/2018/08/28/when-women-arecalled-aggressive-at-work/\#53dcbc4d7bc8

Goodyear, S. (2019, October 17). 'I'm not going to reconsider': Toronto's top librarian refuses to bar speaker critical of transgender rights. CBC Radio. https://www.cbc.ca/radio/asithappens/i-m-not-going-to-reconsider-toronto-s-toplibrarian-refuses-to-bar-speaker-critical-of-transgender-rights-1.5324431

Murphy, M. (2019, October 31). Gender identity: What does it mean for society, the law, and women-A talk by Meghan Murphy [Video]. YouTube. https://www.youtube.com/watch?v=jlzXSLFeAxQ

Neigel, C. (2019, October 26). Library meeting rooms and librarianship's existential crisis? Resistant Librarian. https://resistantlibrarian.home.blog/2019/10/26/librarymeetings-rooms-librarianships-existential-crisis/ 
Nickle, D. (2019, October 29). Murphy talk marks dark chapter in Toronto's troubled history of speech. toronto.com. https://www.toronto.com/opinion-story/9666715murphy-talk-marks-dark-chapter-in-toronto-s-troubled-history-of-speech/

Slaughter, G., \& MacLeod, M. (2019, October 29). Hundreds protest controversial writer outside Toronto library. CTV News. https://www.ctvnews.ca/

Smith, D. G., Rosenstein, J. E., \& Nikolov, M. C. (2018, May 25). The different words we use to describe male and female leaders. Harvard Business Review. https://hbr.org/2018/05/the-different-words-we-use-to-describe-male-and-femaleleaders

The Canadian Press. (2019, October 29). Hundreds protest Toronto library event featuring controversial speaker. CBC News. https://www.cbc.ca/news/canada/toronto/megan-murphy-toronto-library-protest1.5339909

Wilson, S. (2008). Research is ceremony: Indigenous research methods. Fernwood Publishing. 